Supporting Information: Darren B. Hansen, Stefanie B. Bumpus, Zachary D. Aron, Neil L. Kelleher, and Christopher T. Walsh

\title{
The Loading Module of Mycosubtilin: an Adenylation Domain With Fatty Acid Selectivity
}

Darren B. Hansen, Stefanie B. Bumpus, Zachary D. Aron, Neil L. Kelleher, and Christopher T. Walsh*

Department of Biological Chemistry and Molecular Pharmacology, Harvard Medical School, 240 Longwood Avenue, Boston, Massachusetts 02115, and Department of Chemistry, University of Illinois, 600 South Mathews Avenue, Urbana, Illinois 61801

\section{Supporting Information Contents}

I. Bacterial strains, plasmids, materials and instrumentation .......................................

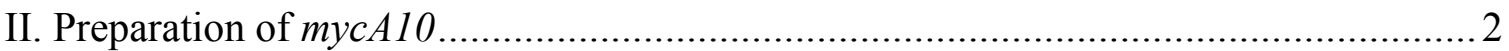

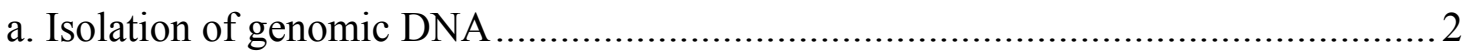

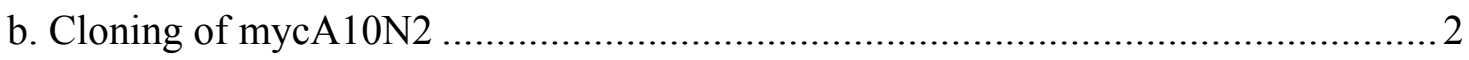

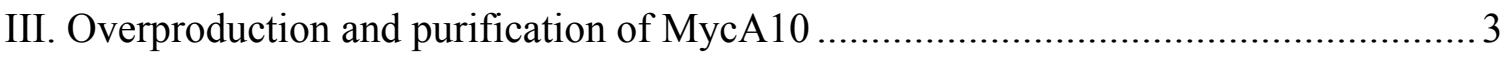

Figure S1. Purified recombinant apo and holo MycA10....................................... 4

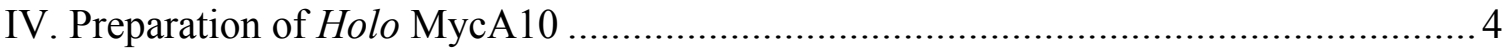

V. Phosphopantetheinylation of MycA10 by trichloroacetic acid (TCA) precipitation ..... 4

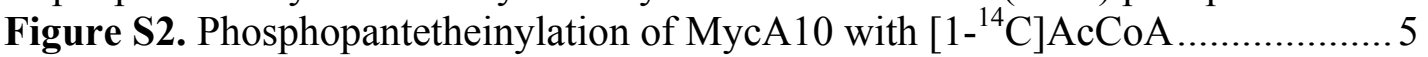

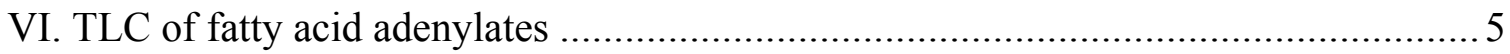

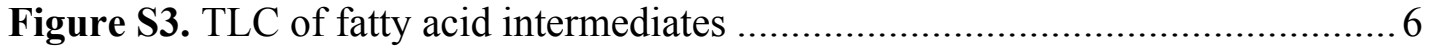

VII. SDS-Page of MycA10 loading ……….............................................................. 6

Figure S4. MycA10 loading with decanoic acid and decanoic-CoA ....................... 7

VIII. Chase experiment to examine substrate specificity in MycA10 loading:.................. 7

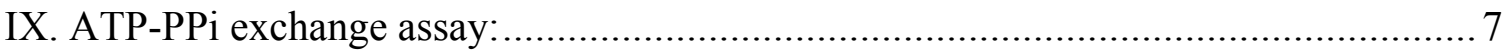

Figure 5S. ATP-PPi exchange time course with MycA10 and various fatty acids.... 8

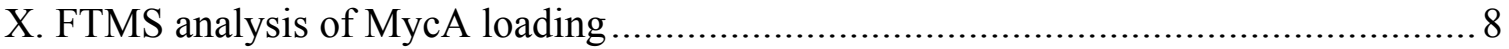

a. Generation of samples for active site mapping of holo MycA10 ........................... 8

b. Generation of decanoic acid loaded MycA10 ........................................................ 9

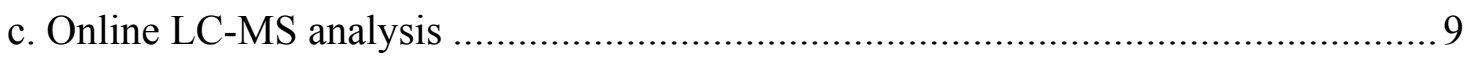

Figure S6. Active site mapping of MycA10 .................................................... 10

Figure S7. Theoretical PPant ejection products. ................................................... 11 
Table S1. Active site peptide (MycA10 amino acid residues 587-681) mass values.

\section{Bacterial strains, plasmids, materials and instrumentation}

Chemically competent TOP10 and BL21(DE3) E. coli were purchased from Invitrogen. SDS-PAGE gels were purchased from BioRad or Invitrogen. pET28a plasmid was purchased from Novagen. All restriction endonucleases and T4 Quick DNA ligase were obtained from New England Biolabs. Synthetic DNA oligonucleotides were purchased from Intergrated DNA Technologies and used without further purification. Polymerase chain reactions were run using Pfu Turbo available from Stratagene. NiNTA chromatography resin was purchased from Qiagen. Genomic DNA was purified by DNeasy Kit from Qiagen. All other DNA isolation and purification was performed using a QIAprep Spin Miniprep Kit from Qiagen. DNA sequencing was performed at the Molecular Biology Core Facilities of the Dana-Farber Cancer Institute (Boston, MA). [1$\left.{ }^{14} \mathrm{C}\right]$ Acetyl-CoA and $\left[{ }^{32} \mathrm{P}\right]$ sodium pyrophospate were obtained from Perkin Elmer, and $\left[1-{ }^{14} \mathrm{C}\right]$ decanoic acid was obtained from Morvek Radiochemicals (Brea, CA). Benzonase Nuclease HC purity $>90 \%$ was obtained from Novagen, Complete EDTAfree protease inhibitor cocktail tablets were purchased from Roche. All other materials were purchased from Sigma Aldrich.

\section{Preparation of mycA10}

\section{a. Isolation of genomic DNA}

Bacillus subtilis was obtained from ATCC (strain 6633), inoculated in nutrient broth and grown at $30{ }^{\circ} \mathrm{C}$ for $24 \mathrm{~h}$ with agitation. Genomic DNA was isolated using the DNeasy Kit from Qiagen.

\section{b. Cloning of mycA10N2}

Amplification of the mycA10 open reading frame from genomic DNA was accomplished using Pfu Turbo DNA polymerase using primers MN1 (5'- GTA CAG GCT AGC ATG TAT ACC AGT CAA TTT CAA-3') and MC1 (5'- AAG GAA GTC GAC TCA TTG CTT GAT TTC GGA ATG GTT-3'). NheI and SalI restriction sites are underlined. The resulting $2.0 \mathrm{~kb}$ PCR product was purified by agarose gel electrophoresis, digested with NheI and SalI and ligated into similarly digested pET28a, yielding a construct mycA10pET28a with a $N$-terminal hexahistidine tag. Plasmid $m y c A 10$-pET28a was transformed in TOP10 chemical competent E. coli and grown on Luria-Bertani (LB)-agar plates supplemented with kanamycin $(50 \mu \mathrm{g} / \mathrm{mL})$. Sequencing of selected colonies confirmed mycA10-pET28a sequence was identical to gene sequence from B. subtilis ATCC 6633 as reported by Duitmann et al. 


\section{Overproduction and purification of MycA10}

The construct mycA10-pET28a was transformed in chemically competent BL21(DE3) E. coli cells and plated on LB-agar plates supplemented with kanamycin $(50 \mu \mathrm{g} / \mathrm{mL})$. A single colony was picked and cultured in $400 \mathrm{~mL}$ of LB supplemented with kanamycin $(50 \mu \mathrm{g} / \mathrm{mL})$ and grown overnight at $37{ }^{\circ} \mathrm{C}$. Six $4 \mathrm{~L}$ Fernbach flasks containing $2 \mathrm{~L}$ of LB supplemented with kanamycin $(50 \mu \mathrm{g} / \mathrm{mL})$ were inoculated with $40 \mathrm{~mL}$ of the overnight culture. The cultures were grown at $37^{\circ} \mathrm{C}$ with rapid agitation for $1 \mathrm{~h}$ before the temperature was shifted to $15^{\circ} \mathrm{C}$ and the $\mathrm{OD}_{600}$ was monitored until it reached 0.5 , then were induced with IPTG $(500 \mu \mathrm{M})$, and incubated an additional $20 \mathrm{~h}$. The cells were harvested by centrifugation $(8 \mathrm{~min}$ at $6000 \mathrm{~g}$ ), resuspended in lysis buffer $[20 \mathrm{mM}$ Tricine ( $\mathrm{pH} 8.0$ ), $20 \mathrm{mM} \mathrm{NaCl}, 5.0 \mathrm{mM}$ imidazole, $5.0 \mathrm{mM} \mathrm{MgCl} 2,1.0 \mathrm{mM} \mathrm{DTT}$, and 10\% glycerol], at approximately $4 \mathrm{~mL}$ per gram of cell pellet. To this mixture 1 Complete EDTA-free protease inhibitor cocktail tablet was added, along with $15 \mu \mathrm{L}$ of Benzonase Nuclease and $100 \mathrm{mg}$ of lysozyme. The mixture was lysed by one passage though a French press at $7000-10000 \mathrm{psi}$, then clarified at by centrifugation at $35000 \mathrm{~g}$ for $35 \mathrm{~min}$. $\mathrm{Ni}-\mathrm{NTA}$ resin $(4.0 \mathrm{~mL}$ slurry for 12L of culture) was added and allowed to bind for $1 \mathrm{~h}$ at $4^{\circ} \mathrm{C}$. The resin was washed with 4 column volumes of wash buffer $[20 \mathrm{mM}$ Tricine $(\mathrm{pH}$ 8.0), $300 \mathrm{mM} \mathrm{NaCl}, 5.0 \mathrm{mM}$ imidazole, $5.0 \mathrm{mM} \mathrm{MgCl}_{2}, 1.0 \mathrm{mM}$ DTT, and 10\% glycerol], then 2 column volumes of $20 \mathrm{mM}$ imidazole buffer $[20 \mathrm{mM}$ Tricine ( $\mathrm{pH} 8.0)$, $300 \mathrm{mM} \mathrm{NaCl}, 20.0 \mathrm{mM}$ imidazole, $5.0 \mathrm{mM} \mathrm{MgCl}$, $1.0 \mathrm{mM}$ DTT, and $10 \%$ glycerol], and the bound protein was eluted with 5 column volumes of elution buffer $[20 \mathrm{mM}$ Tricine ( $\mathrm{pH} 8.0$ ), $300 \mathrm{mM} \mathrm{NaCl}, 200.0 \mathrm{mM}$ imidazole, $5.0 \mathrm{mM} \mathrm{MgCl} 2,1.0 \mathrm{mM}$ DTT, and $10 \%$ glycerol]. The fractions containing the desired protein were concentrated to approximately $3.5 \mathrm{~mL}$ total volume and purified by Superdex 200 gel filtration column eluting with $20 \mathrm{mM}$ Tricine ( $\mathrm{pH} 8.0$ ), $50 \mathrm{mM} \mathrm{NaCl}, 2.0 \mathrm{mM} \mathrm{MgCl} 2,1.0 \mathrm{mM}$ DTT and $10 \%$ glycerol. The protein containing fractions were collected, concentrated and flash frozen in liquid nitrogen and stored at $-80{ }^{\circ} \mathrm{C}$. The final protein concentration was determined by Bradford assay. 


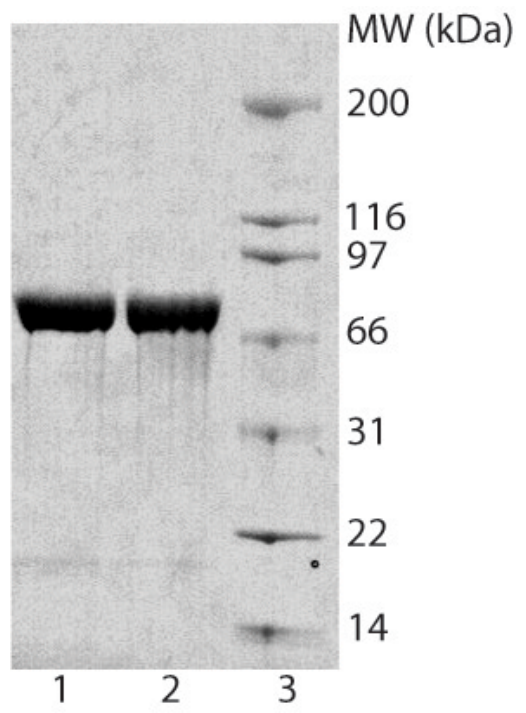

Figure S1. Purified recombinant apo and holo MycA10.

Protein samples were resolved by SDS-PAGE (4-12\%, Bio-Rad) and stained with Coomassie Blue stain. Lane 1. apo MycA10; Lane 2. holo MycA10; Lane 3. Molecular weight markers in $\mathrm{kDa}$.

\section{Preparation of Holo MycA10}

To a $54 \mu \mathrm{M}$ solution of MycA10 in buffer [50 mM Tricine ( $\mathrm{pH} 8.0), 50 \mathrm{mM} \mathrm{NaCl}, 5.0$ $\mathrm{mM} \mathrm{MgCl} 2,2.0 \mathrm{mM}$ DTT and 5\% glycerol] was added Sfp $(10 \mu \mathrm{M})$ and coenzyme A trilithium salt $(250 \mu \mathrm{M})$. The reaction was incubated at $25^{\circ} \mathrm{C}$ for $1 \mathrm{~h}$, then purified directly by Superdex 200 gel filtration column and concentrated and frozen as described above.

\section{Phosphopantetheinylation of MycA10 by trichloroacetic acid (TCA) precipitation}

To MycA10 (5, 10, $20 \mu \mathrm{M})$ in buffer [50 mM Tris (pH 7.5), $50 \mathrm{mM} \mathrm{NaCl,} 5.0 \mathrm{mM}$ $\mathrm{MgCl}_{2}$ and $5.0 \mathrm{mM}$ TCEP] was added $\left[1-{ }^{14} \mathrm{C}\right] \mathrm{AcCoA}(20 \mathrm{mCi} / \mathrm{mmol}, 50 \mu \mathrm{M})$. The reaction was started with by the addition of $\operatorname{Sfp}(1.0 \mu \mathrm{M})$. At $0,5,10,15,30$ and $60 \mathrm{~min}$, $50 \mu \mathrm{L}$ of the reaction mixture was quenched in $0.5 \mathrm{~mL}$ of $10 \%(\mathrm{w} / \mathrm{v}) \mathrm{TCA}$. The protein was pelleted by centrifugation $(16,000 \mathrm{~g}$ for $10 \mathrm{~min})$, and the resulting pellet was washed with $0.5 \mathrm{~mL} 10 \% \mathrm{TCA}$, dissolved in $100 \mu \mathrm{L}$ of formic acid and counted by liquid scintillation counting. The amount of bound radioactivity was converted to \% conversion (based on 1 equivalent of $\left[1-{ }^{14} \mathrm{C}\right] \mathrm{AcCoA}$ binding to 1 equivalent of MycA10) using the specific activity of $\left[1-{ }^{14} \mathrm{C}\right] \mathrm{AcCoA}$. 


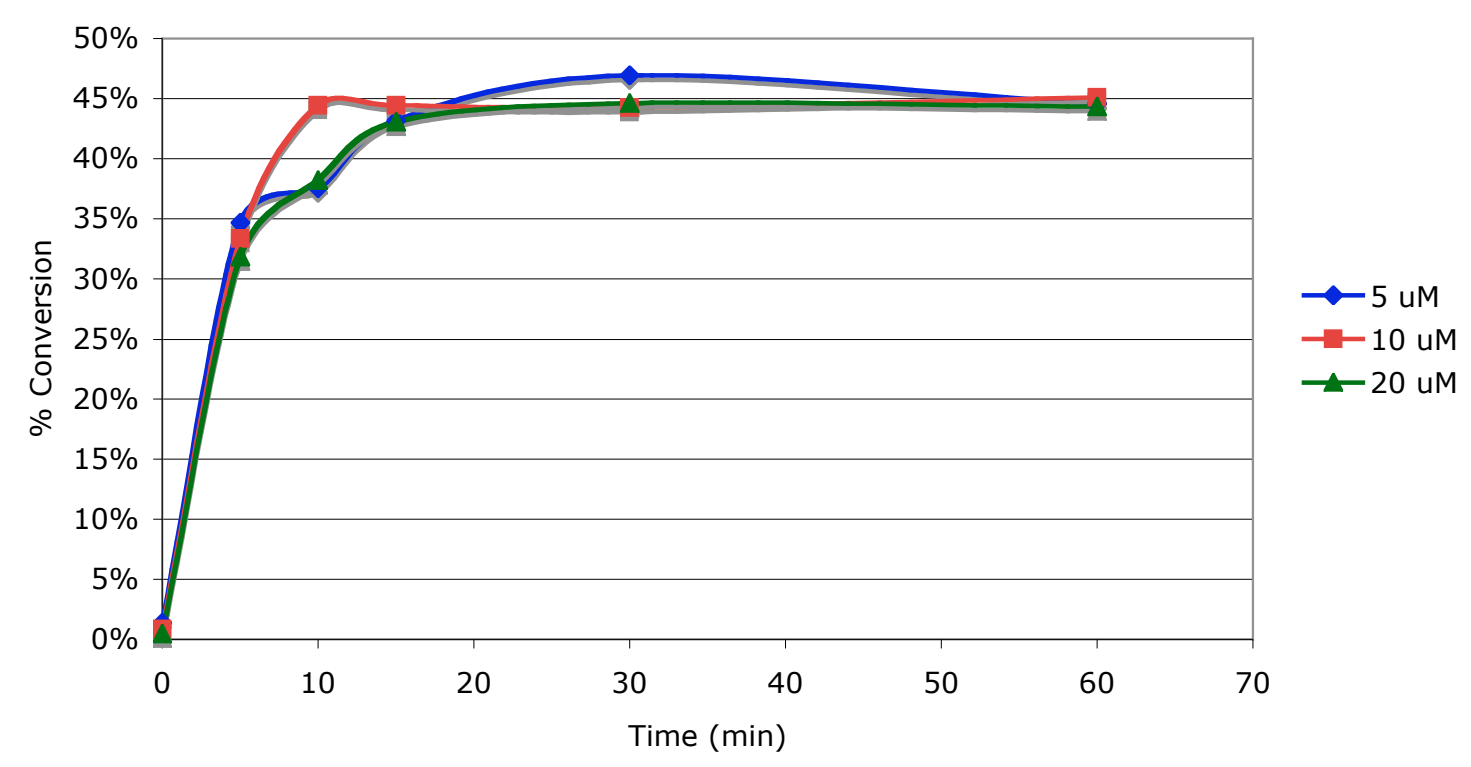

Figure S2. Phosphopantetheinylation of MycA10 with $\left[1-{ }^{14} \mathrm{C}\right] \mathrm{AcCoA}$

\section{TLC of fatty acid adenylates}

The $15 \mu \mathrm{L}$ reaction mixture contained $50 \mathrm{mM}$ Hepes $(\mathrm{pH} 8.0), 8 \mathrm{mM} \mathrm{MgCl} 2, \mathrm{MycA}_{10}$ $(10 \mu \mathrm{M})$ plus a combination of the following materials as listed in Figure S3. The reactions were incubated for $30 \mathrm{~min}$ at $25^{\circ} \mathrm{C}$ then quenched with $5.0 \mathrm{uL}$ of $5 \%$ acetic acid. The reaction mixture was then spotted directly on silica gel TLC plates. The products were resolved on TLC in an n-butanol/acetic acid/water (80:25:40) solvent system. The radioactive spots on TLC were detected using a phosphoimager (Typhoon 9410, GE Healthcare). To confirm the identity of the product the use of $\left[8^{-14} \mathrm{C}\right] \mathrm{ATP}$ and $\left[1-{ }^{14} \mathrm{C}\right]$ decanoic acid were alternated to give spots of identical $\mathrm{R}_{f}$. Addition of CoA (100 $\mu \mathrm{M})$ to the reaction mixture did not result in any additional products by TLC. 


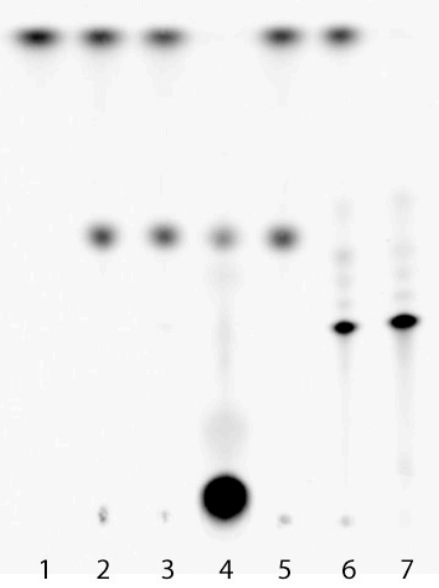

Figure S3. TLC of fatty acid intermediates

1. $\left[1-{ }^{14} \mathrm{C}\right]$ decanoic acid $(100 \mu \mathrm{M})$ standard

2. $\left[1-{ }^{14} \mathrm{C}\right]$ decanoic acid $(100 \mu \mathrm{M}), \operatorname{ATP}(1.0 \mathrm{mM})$

3. $\left[1-{ }^{14} \mathrm{C}\right]$ decanoic acid $(100 \mu \mathrm{M})$, ATP $(1.0 \mathrm{mM})$, CoA $(1.0 \mathrm{mM})$

4. decanoic acid $(100 \mu \mathrm{M}),\left[8-{ }^{14} \mathrm{C}\right]$ ATP $(1.0 \mathrm{mM})$

5. $\left[1-{ }^{14} \mathrm{C}\right]$ decanoic acid $(100 \mu \mathrm{M})$, ATP $(1.0 \mathrm{mM})$

6. $\left[1-{ }^{14} \mathrm{C}\right]$ decanoic acid $(100 \mu \mathrm{M}),\left[1-{ }^{14} \mathrm{C}\right]$ decanoic-CoA $(100 \mu \mathrm{M})$

7. $\left[1-{ }^{14} \mathrm{C}\right]$ decanoic-CoA standard.

\section{SDS-Page of MycA10 loading}

To the reaction buffer [50 mM Tris ( $\mathrm{pH} 7.5), 50 \mathrm{mM} \mathrm{NaCl}, 5.0 \mathrm{mM} \mathrm{MgCl} 2$ and $5.0 \mathrm{mM}$ TCEP] was added MycA10 $(10 \mu \mathrm{M})$. In one experiment was added $\left[1-{ }^{14} \mathrm{C}\right]$ decanoic acid $(100 \mu \mathrm{M})$ and ATP $(5 \mathrm{mM})$, in the second experiment was added just $\left[1-{ }^{14} \mathrm{C}\right]$ decanoicCoA $(100 \mu \mathrm{M})$. The reaction was incubated at $25^{\circ} \mathrm{C}, 50 \mu \mathrm{L}$ aliquots were taken at five time points $(0,5,10,20$ and $30 \mathrm{~min})$, and the reactions were quenched in $6 \mathrm{x}$ Laemlli SDS-PAGE loading buffer and placed in boiling water for 5 minutes. The proteins were resolved on $4-12 \%$ Nupage (Invitrogen) SDS-PAGE gel. The gel was then transferred to a PVDF membrane at $100 \mathrm{~V}$ for $60 \mathrm{~min}$ at $4{ }^{\circ} \mathrm{C}$, then stained with Coomassie Blue and the radioactive bands were detected using a phosphoimager. 
Coomassie

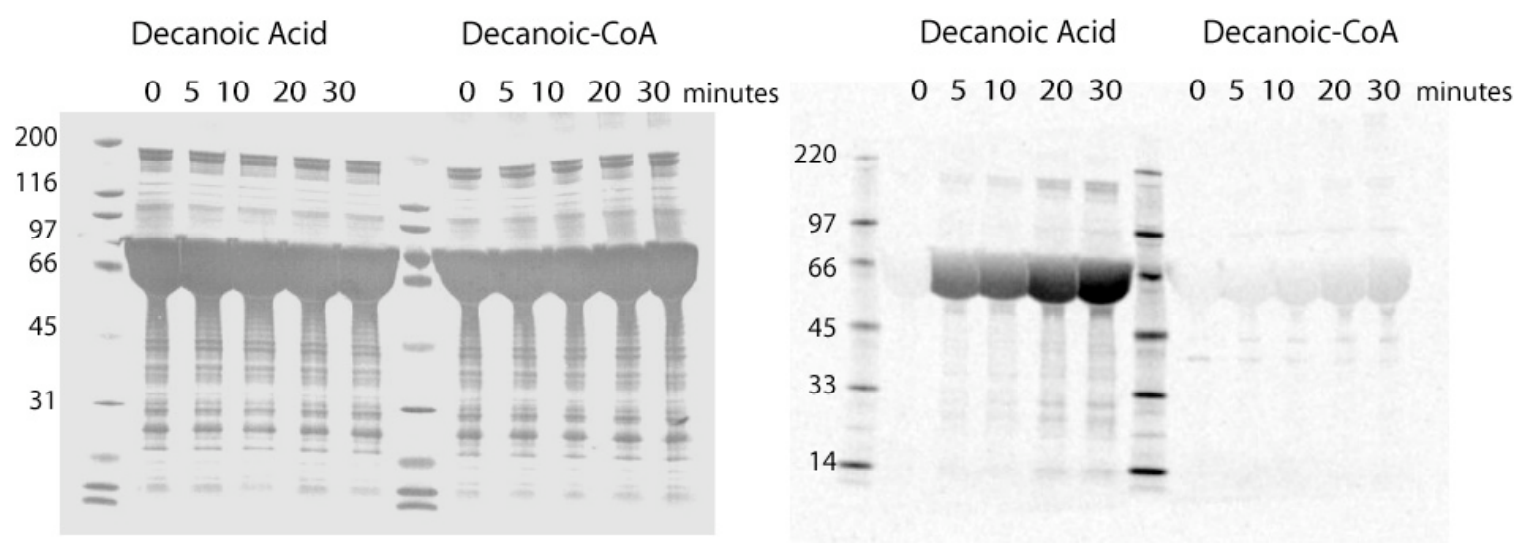

Figure S4. MycA10 loading with decanoic acid and decanoic-CoA

\section{Chase experiment to examine substrate specificity in MycA10 loading:}

To the reaction buffer [50 mM Tris ( $\mathrm{pH} 7.5$ ), $50 \mathrm{mM} \mathrm{NaCl}, 5.0 \mathrm{mM} \mathrm{MgCl} 2$ and $5.0 \mathrm{mM}$ TCEP] was added MycA10 $(10 \mu \mathrm{M})$, ATP $(5.0 \mathrm{mM})$, and the putative substrate $(100$ $\mu \mathrm{M})$. The reaction was incubated at $25^{\circ} \mathrm{C}$ for $30 \mathrm{~min}$, then $100 \mu \mathrm{L}$ reaction aliquots were applied to individual Bio-Spin 6 micro gel filtration columns (Bio-Rad) that had been prequilibrate with the reaction buffer. The protein fraction of the applied sample was eluted from the microspin column as directed by the manufacturer's instructions. $50 \mu \mathrm{L}$ of each protein fraction was supplemented with ATP $(5.0 \mathrm{mM})$ and $\left[1-{ }^{14} \mathrm{C}\right]$ decanoic acid $(100 \mu \mathrm{M})$. The reactions were incubated at $25^{\circ} \mathrm{C}$ for $30 \mathrm{~min}$ then quenched in $6 \mathrm{x}$ Laemlli SDS-PAGE loading buffer and placed in boiling water for $5 \mathrm{~min}$. The proteins were resolved on $4-12 \%$ Nupage (Invitrogen) SDS-PAGE gel. The gel was then transferred to a PVDF membrane at $100 \mathrm{~V}$ for $60 \mathrm{~min}$ at $4^{\circ} \mathrm{C}$, then stained with Coomassie Blue and the radioactive bands were detected using a phosphoimager.

\section{ATP-PPi exchange assay:}

To the reaction buffer [50 $\mathrm{mM}$ Tricine ( $\mathrm{pH} 8.0), 10 \mathrm{mM} \mathrm{MgCl} 2$ and $5.0 \mathrm{mM}$ DTT] was added MycA10 $(5 \mu \mathrm{M}),\left[{ }^{32} \mathrm{P}\right]-\mathrm{NaPP}_{\mathrm{i}}(1.0 \mathrm{mM}, 1.0 \mu \mathrm{Ci} / \mathrm{umol})$ and fatty acids $(100 \mu \mathrm{M})$ or no fatty acid (control). The reaction was started with the addition of ATP $(5.0 \mathrm{mM})$. At $0,5,10,15,30,60$ min time points, $100 \mu \mathrm{L}$ of the reaction mixture was quenched with $500 \mu \mathrm{L}$ of a charcoal solution $(500 \mu \mathrm{L}$ of $1.6 \%(\mathrm{w} / \mathrm{v})$ activated charcoal, $4.46 \%(\mathrm{w} / \mathrm{v})$ tetrasodium pyrophosphate, and $3.5 \%$ perchloric acid in water). The charcoal solution was pelleted by centrifugation, washed twice with wash buffer $(500 \mu \mathrm{L}$ of $4.46 \%(\mathrm{w} / \mathrm{v})$ tetrasodium pyrophosphate, $3.5 \%$ perchloric acid in water), then resuspended in $500 \mu \mathrm{L}$ water and the bound radioactivity was determined by liquid scintillation counting and plotted versus time. Contaminating fatty acids that co-purify with the protein give a high 
background rate in the absence of any additional fatty acid complicated analysis of this assay.

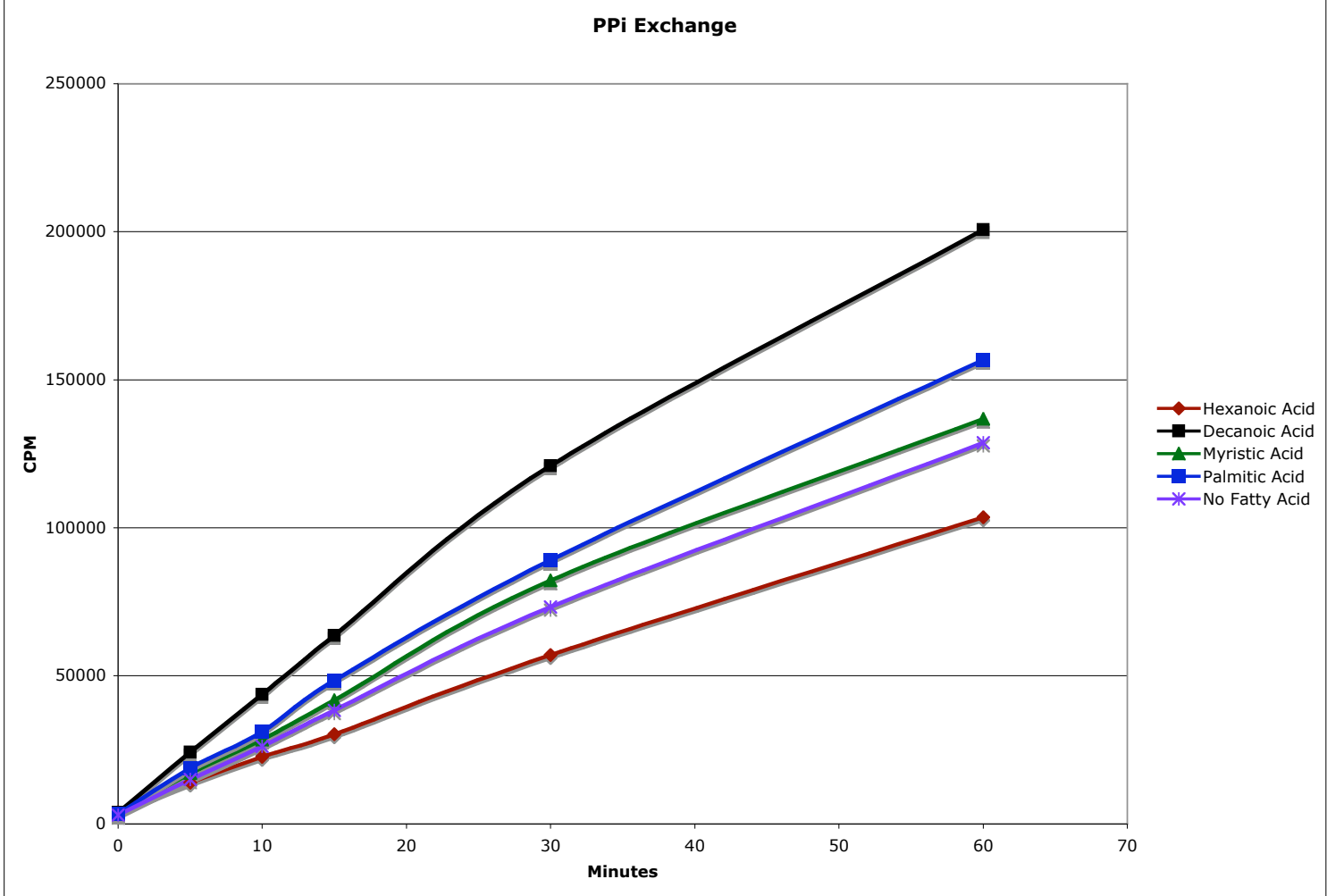

Figure 5S. ATP-PPi exchange time course with MycA10 and various fatty acids

\section{FTMS analysis of MycA loading}

a. Generation of samples for active site mapping of holo MycA10

To the reaction buffer (50 mM HEPES, $50 \mathrm{mM} \mathrm{NaCl}, 2 \mathrm{mM}$ DTT, $50 \mathrm{mM} \mathrm{MgCl}$ ) 34 $\mu \mathrm{M}$ apo MycA10, $7 \mu \mathrm{M}$ Sfp, and $0.4 \mathrm{mM} \mathrm{CoA}$ were added to a final volume of $100 \_\mathrm{L}$, and incubated for 1.25 hours at $30^{\circ} \mathrm{C}$ to generate holo MycA10. CoA was omitted as an apo MycA10 control. For each reaction, 20 _g of sequencing-grade trypsin (Promega) were resuspended in $20 \_$L trypsin resuspension buffer and activated at $30^{\circ} \mathrm{C}$ for $15 \mathrm{~min}$. The activated trypsin was added to 55 _ $0.1 \mathrm{M} \mathrm{NH}_{4} \mathrm{HCO}_{3}(\mathrm{pH} 7.8)$ and the entire volume added to the reaction. The digestion was incubated for 15 minutes at $30^{\circ} \mathrm{C}$, and then quenched by addition of $10 \%$ formic acid to a final volume of 500 _L. All reactions were completed in duplicate. 


\section{b. Generation of decanoic acid loaded MycA10}

To the reaction buffer (50 mM HEPES, $50 \mathrm{mM} \mathrm{NaCl}, 2 \mathrm{mM}$ DTT, $50 \mathrm{mM} \mathrm{MgCl} 2$ ) was added $34 \mu \mathrm{M}$ holo MycA10, $1 \mathrm{mM}$ decanoic acid and $2 \mathrm{mM}$ ATP to a final volume of $100 \_\mathrm{L}$, and incubated for 1.25 hours at $30^{\circ} \mathrm{C}$ to generate decanoic acid loaded MycA10. As a control, holo MycA10 was incubated in reaction buffer in the presence of decanoic acid but absence of ATP. Samples were prepared for FTMS analysis as above.

\section{c. Online LC-MS analysis}

All mass spectrometric (MS) analyses were performed on a 7 Tesla LTQ-FT mass spectrometer (ThermoFisher, San Jose, CA). Separations were performed on a Jupiter C18 Column (4.6 x $150 \mathrm{~mm}$, Phenomenex) equilibrated with Buffer A, using a gradient from $5 \% \mathrm{~B}$ to $95 \% \mathrm{~B}$ over 80 minutes, where $\mathrm{A}$ was $\mathrm{H}_{2} \mathrm{O}+0.1 \%$ formic acid and $\mathrm{B}$ was acetonitrile $+0.1 \%$ formic acid. Each reaction was analyzed twice. The first MS experiment collected MS and $\mathrm{MS}^{2}$ data on tryptic peptides for peptide sequencing and active site mapping. Data dependent $\mathrm{MS}^{2}$ was collected on the top three peaks in each parent spectrum. MS and $\mathrm{MS}^{2}$ data were analyzed with the program cRAWler, developed in house, and fragmentation data were searched against a custom ProSightPC database (ThermoFisher, San Jose, CA). Mass spectra for apo, holo, and decanoic acid loaded MycA10 are shown in Figure S5. In the second MS experiment, the phosphopantethienyl (PPant) ejection assay was performed on the tryptic peptide ions, and expected PPant ejection ions are shown in Figure S6. ${ }^{11} \mathrm{MS}^{2}$ data were collected on the top three peaks in each broadband spectrum with $m / z<900$. The value of $900 \mathrm{~m} / \mathrm{z}$ was selected because this is the highest parent ion $\mathrm{m} / \mathrm{z}$ for which both PPant ejection ions can be detected because of the $1 / 3$ rule present in ion trap fragmentation. PPant ejection data and $\mathrm{MS}^{2}$ data were combined for the characterization of MycA10 loading with decanoic acid (Table S1). 

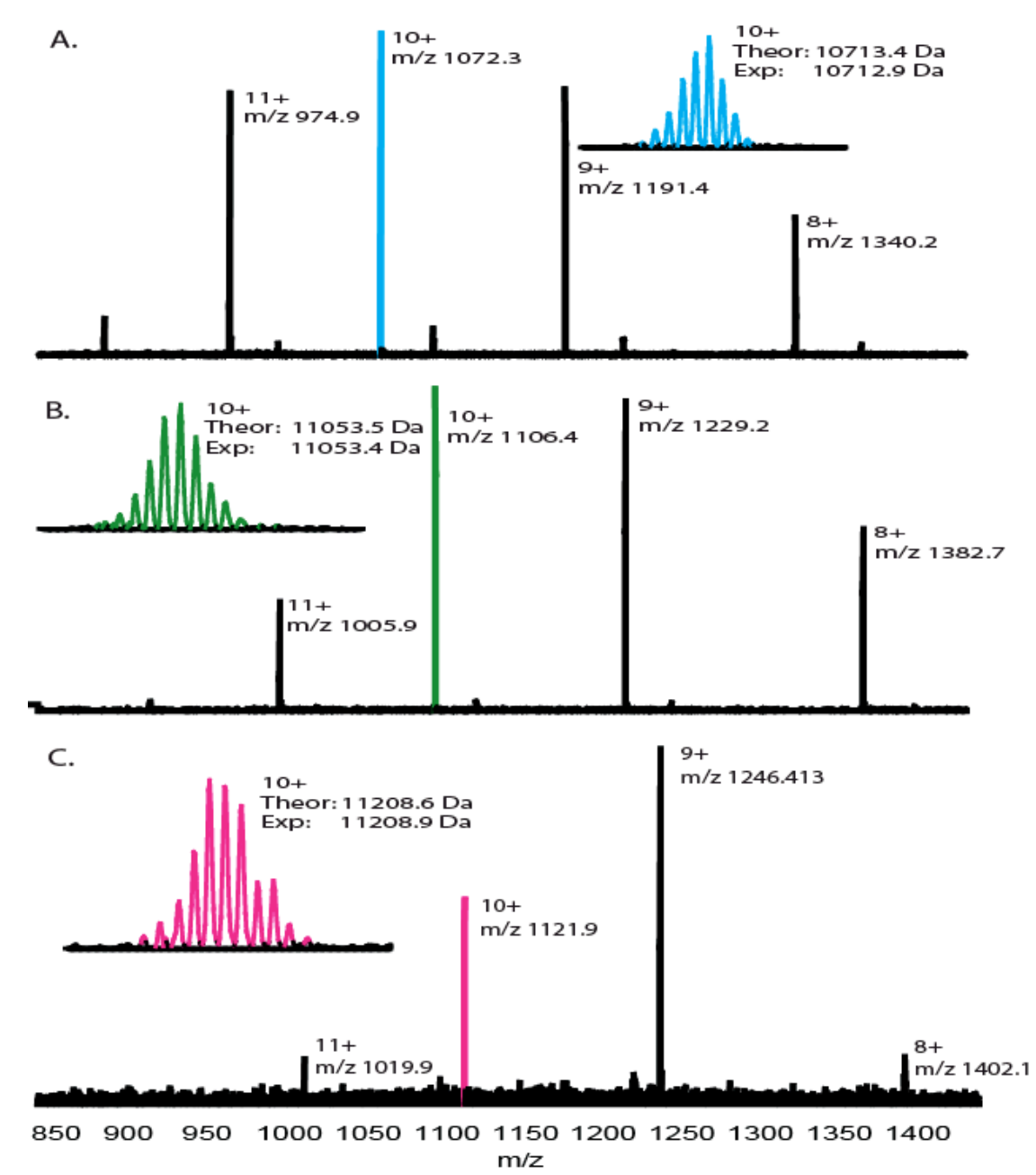

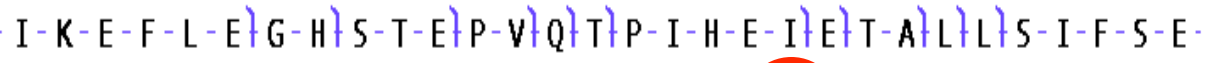
$V-M-D-G-K-K-I-H-L-N-D-H-Y+F-D-M-G-A-T-S-L-Q-L-S-Q-I-A-E-R-I-$

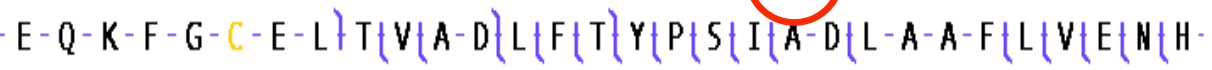
S- E- I-K-Q -

Figure S6. Active site mapping of MycA10.

a) Apo active site tryptic peptide with six missed cleavages as identified by $\mathrm{MS}^{2}$; inset: enlargement of 10+ charge state of apo peptide b) Holo active site tryptic peptide with six missed cleavages as identified by $\mathrm{MS}^{2}$; inset: enlargement of 10+ charge state of holo peptide. c) Decanoic acid loaded active site tryptic peptide with six missed cleavages as identified by $\mathrm{MS}^{2}$; inset: enlargement of $10+$ charge state of decanoic acid loaded peptide d) The PPant modification was localized to two serine residues on the holo peptide, one of which is predicted to be the active site serine (circled in red). 
A.<smiles>CC1(C)CC(O)C(NCCC(=O)NCCS)O1</smiles>

Theoretical Mass: 261.1273 Da<smiles>CC(C)(COP(=O)(O)O)C(O)C(=O)NCCC(=O)NCCS</smiles>

Theoretical Mass: 359.1042 Da
B.<smiles>CCCCCCCCCC(=O)SCCNC(=O)CCNC1OC(C)(C)CC1O</smiles>

Theoretical Mass: $415.2631 \mathrm{Da}$

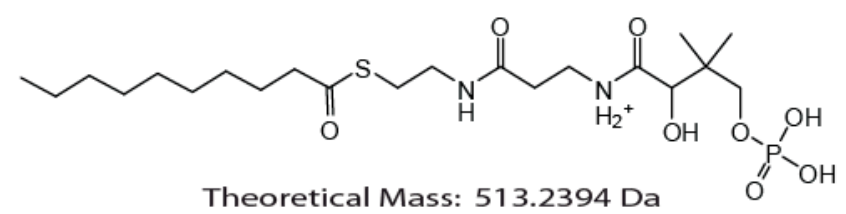

Theoretical Mass: 513.2394 Da

Figure S7. Theoretical PPant ejection products.

a) Holo MycA10 PPant ejection products. b) Decanoic acid loaded MycA10 PPant ejection products.

Table S1. Active site peptide (MycA10 amino acid residues 587-681) mass values.

\begin{tabular}{|c|c|c|c|c|c|}
\hline $\begin{array}{c}\text { Protein } \\
\text { Form }\end{array}$ & $\begin{array}{c}\text { Theoretical } \\
\text { Mass }\end{array}$ & $\begin{array}{c}\text { Experimental } \\
\text { Mass }\end{array}$ & $\begin{array}{c}\text { Theoretical } \\
\text { Mass Shift } \\
\text { from apo } \\
\text { MycA10 }\end{array}$ & $\begin{array}{c}\text { Experimental } \\
\text { Mass Shift } \\
\text { from apo } \\
\text { MycA10 }\end{array}$ & $\begin{array}{c}\text { Error from } \\
\text { Theoretical } \\
\text { Mass } \\
\text { (ppm) }\end{array}$ \\
\hline $\begin{array}{c}\text { Apo } \\
\text { MycA10 }\end{array}$ & $10713.4 \mathrm{Da}$ & $10712.9 \mathrm{Da}$ & $0.0 \mathrm{Da}$ & $-0.7 \mathrm{Da}$ & -46.7 \\
\hline $\begin{array}{c}\text { Holo } \\
\text { MycA10 }\end{array}$ & $11053.5 \mathrm{Da}$ & $11053.4 \mathrm{Da}$ & $340.1 \mathrm{Da}$ & $340.0 \mathrm{Da}$ & -9.0 \\
\hline $\begin{array}{c}\text { Decanoic } \\
\text { Acid } \\
\text { Loaded } \\
\text { MycA10 }\end{array}$ & $11208.6 \mathrm{Da}$ & $11208.9 \mathrm{Da}$ & $495.2 \mathrm{Da}$ & $495.5 \mathrm{Da}$ & 26.8 \\
\hline
\end{tabular}

